\title{
HUBUNGAN AKSESIBILITAS LAPORAN KEUANGAN TERHADAP AKUNTABILITAS PUBLIK PADA PEMERINTAH KABUPATEN BENGKULU UTARA
}

\author{
Mirta Wijaya \\ Neri Susanti \\ Sulisti Afriani \\ Fakultas Ekonomi Universitas Dehasen Bengkulu \\ nerrysusanti@yahoo.com
}

\begin{abstract}
ABSTRAK
Mirta Wijaya, Neri Susanti dan Sulisti Afriani: Tujuan dari penelitian ini adalah untuk mengetahui hubungan antara aksesibilitas laporan keuangan terhadap akuntabilitas publik pada Pemerintah Daerah Kabupaten Bengkulu Utara. Metode pengambilan sampel secara purposive sampling. Metode analisis menggunakan analisis Korelasi Rank Spearman. Dari hasil penelitian disimpulkan terdapat hubungan yang signifikan antara aksesibilitas laporan keuangan dan akuntabilitas publik pada Pemerintah Kabupaten Bengkulu Utara yang terlihat dari nilai $r s$ hitung $>r s$ tabel $(0,63>0,450)$. Sedangkan kekuatan hubungan antara aksesibilitas laporan keuangan dengan akuntabilitas publik adalah kuat yang telihat dari nilai korelasi 0,63 berada pada interval 0,60 - 0,799 dengan interprestasi kuat.
\end{abstract}

\section{ABSTRACT}

Mirta Wijaya, Neri Susanti dan Sulisti Afriani; The purpose of this study is to determine the relationship between the accessibility of financial statements to public accountability to the Local Government of North Bengkulu Regency. Sampling method by purposive sampling. Analysis method using Spearman Rank Correlation analysis. From the research result, it can be concluded that there is a significant correlation between accessibility of financial report and public accountability to North Bengkulu Regency Government which seen from rs count> rs table $(0,63>0,450)$. While the strength of the relationship between the accessibility of the financial statements with public accountability is strongly apparent from the correlation value of 0.63 is at the interval of 0.60 - 0.799 with strong interpretation.

Key Words: Financial reports, accessibility of financial statements, public accountability

\section{PENDAHULUAN}

Pelaksanaan otonomi daerah identik dengan adanya tuntutan Good Governance dalam rangka efektifitas dan efisiensi pembangunan daerah dalam kerangka otonomi memerlukan prasyarat berupa tata pemerintahan yang baik dan bersih. Terselenggaranya Good Governance merupakan prasyarat utama untuk mewujudkan aspirasi masyarakat dalam mencapai tujuan dan cita-cita Bangsa dan Negara.

Pada dasarnya terdapat tiga pilar utama didalam mewujudkan Good Governance, yaitu : Akuntabilitas, Transparasi, dan Partisipasi. Salah satu upaya dalam penerapan prinsip-prinsip dasar Good Governance ini adalah aksesibilitas laporan keuangan. Aksesibilitas laporan keuangan adalah kemudahan bagi seseorang untuk memperoleh informasi mengenai laporan keuangan. Laporan keuangan harus dapat dimengerti dan tersedia bagi mereka yang membutuhkan informasi keuangan tersebut.

Laporan keuangan merupakan laporan yang terstruktur mengenai posisi keuangan dan transaksi-transaksi yang dilakukan oleh suatu entitas pelaporan. Laporan keuangan ini wajib disusun dengan baik oleh pemerintah daerah sesuai amanat Peraturan Pemerintah Nomor 71 Tahun 2010 tentang Standar Akuntansi Pemerintahan, meliputi: (1) Laporan Realisasi Anggaran, (2) Neraca, (3) Laporan Arus Kas, dan (4) Catatan atas Laporan Keuangan.Tujuan umum laporan keuangan adalah untuk menyajikan informasi mengenai posisi keuangan, realisasi anggaran, arus kas, dan kinerja keuangan suatu entitas pelaporan ynag bermanfaat bagi para pengguna dalam membuat dan mengevaluasi keputusan mengenai alokasi sumber daya.

Pemerintah Daerah Kabupaten Bengkulu Utara sebagai salah satu pemerintah daerah yang diberi amanat untuk menjalankan otonomi daerah telah menjalankan amanat Undang-Undang untuk mempublikasikan laporan keuangan kepada DPRD dan masyarakat secara akuntabel melalui media masa. Namun dalam upaya aksesibilitas laporan keuangan secara rinci, pemerintah daerah memberikan 
batasan dalam memperoleh laporan keuangan daerah tersebut agar tidak disalah gunakan oleh oknumoknum yang tidak bertanggungjawab.

Aksesibilitas laporan keuangan daerah Kabupaten Bengkulu Utara memberikan manfaat sebagai upaya percepatan perolehan informasi mengenai laporan keuangan daerah. Akuntabilitas yang efektif tergantung kepada akses publik terhadap laporan pertanggungjawaban maupun laporan temuan yang dapat dibaca dan dipahami. Dengan akses yang baik, mudah diperoleh, mudah dibaca dan mudah dipahami mencerminkan transparansi pemerintah daerah dalam menjalankan pemerintahannya. Sehingga dalam mempertanggungjawabkan pengelolaan keuangan daerah dapat dinilai apakah pemerintah daerah tersebut berhasil menjalankan tugasnya dengan baik atau tidak.

Penelitian ini bertujuan untuk mengetahui hubungan antara aksesibilitas laporan keuangan terhadap akuntabilitas publik pada Pemerintah Daerah Kabupaten Bengkulu Utara. Dengan pokok bahasan mengenai aksesibilitas laporan keuangan terhadap akuntabilitas publik pada Pemerintah Daerah Kabupaten Bengkulu Utara, yang dibutuhkan oleh DPRD, Bappeda, dan lembaga pendidikan/mahasiswa sebagai responden dalam penelitian ini. Metode pengambilan sampel dilakukan secara purposive sampling. Dengan metode analisis menggunakan analisis Korelasi Rank Spearman.

\section{TINJAUAN LITERATUR Laporan Keuangan}

Laporan keuangan merupakan suatu informasi yang menggambarkan kondisi suatu perusahan, dimana selanjutnya itu akan menjadi suatu informasi yang menggambarkan tentang kinerja suatu perusahaan. Laporan keuangan merupakan alat yang sangat penting untuk memperoleh informasi sehubungan dengan posisi keuangan dan hasil-hasil yang dicapai oleh perusahan yang bersangkutan. Dengan begitu laporan keuangan diharapkan akan membantu bagi para pengguna untuk membuat keputusan ekonomi yang bersifat finansial. (Fahmi, 2012: 22-23)

Menurut Mardiasmo (2005 : 13) mengatakan: "Laporan keuangan pemerintah merupakan hak publik yang harus diberikan oleh pemerintah, baik pusat maupun daerah. Hak publik atas informasi keuangan muncul sebagai konsekuensi konsep pertanggungjawaban publik. Pertanggungjawaban publik mensyaratkan organisasi publik untuk memberikan laporan keuangan sebagai bukti pertanggungjawaban dan pengelolaan (accountability dan sstewardship).

Berdasarkan Laporan Keuangan Dinas Pengelolaan Keuangan dan Aset Daerah (2013 : 3), laporan keuangan daerah terdiri :

a. Laporan Realisasi Anggaran (LRA)

Laporan Realisasi Anggaran menyediakan informasi mengenai realiasi pendapatan, belanja, transfer, surplus/defisit dan pembiayaan dari suatu entitas pelaporan (SKPD) yang masing-masing dibandingkan dengan anggarannya dan menyediakan informasi yang berguna dalam memprediksi sumber daya ekonomi yang akan diterima untuk mendanai kegiatan pemerintah pusat dan daerah dalam periode mendatang dengan cara menyajikan laporan secara komparatif.

b. Neraca (balance sheet) Daerah

Neraca menunjukan laporan tentang harta atau kekayaan daerah, atau keadaan posisi keuangan pada saat tertentu, serta aktiva dan nilai kekayaan daerah selama periode rencana strategi (renstra)

c. Catatan atas Laporan Keuangan (CALK)

Catatan atas Laporan Keuanganadalah catatan tambahan dan informasi yang ditambahkan ke akhir laporan keuangan untuk memberikan tambahan informasi kepada pembaca dengan informasi lebih lanjut. Catatan atas Laporan Keuangan membantu menjelaskan perhitungan item tertentu dalam laporan keuangan serta memberikan penilaian yang lebih komprehensif dari kondisi keuangan perusahaan. Catatan atas Laporan Keuangan dapat mencakup informasi tentang hutang, kelangsungan usaha, piutang, kewajiban kontinjensi, atau informasi kontekstual untuk menjelaskan angka-angka keuangan.

Adapun tujuan dari laporan keuangan ini adalah untuk memberikan informasi kepada pihak yang membutuhkan tentang kondisi suatu perusahaan dari sudut angka-angka dalam satuan moneter. Untuk tujuan tersebut, pelaporan keuangan harus mempertimbangkan kebutuhan para pengguna dan keputusan yang mereka buat.

\section{Aksesibilitas Laporan Keuangan}

Menurut Badudu (2007 : 10) Aksesibilitas adalah:"Tingkat kemudahan untuk mencapai suatu tujuan lokasi, yang menjadi ukuran adalah jarak, waktu tempuh, kelengkapan dan kualitas dari fasilitas yang tersedia".

Menurut Mardiasmo (2005 : 10) Aksesibilitas adalah : 
"Berdasarkan perspektif tata ruang adalah keadaan atau ketersediaan hubungan dari suatu tempat ke tempat lainnya atau kemudahan seseorang atau kendaraan untuk bergerak dari suatu tempat ke tempat lain dengan aman, nyaman, serta kecepatan yang wajar".

Ada beberapa faktor-faktor yang mempengaruhi aksesibilitas laporan keuangan daerah, antara lain: (Riayani, $2014: 4$ )

a. Ketersediaan informasi laporan keuangan

Hal yang paling utama dalam aksesibilitas laporan keuangan daerah yaitu adanya laporan keuangan itu sendiri. Laporan keuangan dibuat sesuai dengan kebutuhan pengguna. Adanya laporan keuangan dapat membantu pihak yang membutuhkan untuk untuk membuat keputusan ekonomi yang bersifat finansial.

b. Kualitas Informasi Laporan Keuangan

c. Media publikasi laporan keuangan

Dalam Undang-Undang Nomor 33 tahun 2004 tentang Perimbangan Keuangan antara Pemerintah Pusat dan Pemerintah Daerah, pasal 103, dinyatakan bahwa "Informasi yang dimuat dalam sistem informasi keuangan daerah (SIKD) adalah data terbuka yang dapat diketahui, diakses dan diperoleh oleh masyarakat". Ini berarti bahwa pemerintah daerah harus membuka akses kepada stakeholdersecara luas atas laporan keuangan yang dihasilkannya.Media publikasi laporan keuangan dapat melalui surat kabar, papan pengumuman, internet, atau dengan cara lainnya.

\section{Akuntabilitas Publik}

Menurut Mulyadi (2002 : 25) menyatakan bahwa : "Akuntabilitas publik mengandung makna bahwa hasil dari suatu entitas kedalam bentuk fungsinya, program dan kegiatan, maupun kebijakan suatu lembaga publik harus dapat dijelaskan dan dipertanggung jawabkan kepada masyarakat (public disclosure), dan masyarakat dapat dengan mudah mengakses informasi dimaksud tanpa hambatan".

Terdapat tiga dimensi akuntabilitas yang harus dipenuhi oleh organisasi sektor publik (badan hukum) menurut Mahsun ( $2012: 43$ ), yaitu :

a. Akuntabilitas Kejujuran dan Akuntabilitas Hukum.

Akuntabilitas kejujuran terkait dengan penghindaran penyalahgunaanjabatan (abuse of power), sedangkan akuntabilitas hukum terkait dengan jaminan adanya kepatuhan terhadap hukum dan peraturan lain yang disyaratkan dalam penggunaan sumber dana publik.

b. Akuntabilitas Proses.

Akuntabilitas proses terkait dengan apakah prosedur yang telah digunakan dalam melaksanakan tugas sudah cukup baik dalam hal kecukupan sistem informasi akuntansi, sistem informasi manajemen dan prosedur administrasi. Akuntabilitas proses termanifestasikan melalui pemberian pelayanan publik yang cepat, responsif, dan murah biaya.

c. Akuntabilitas Program dan Kebijakan

Akuntabilitas program terkait dengan pertimbangan apakah tujuan yang ditetapkan dapat dicapai atau tidak dan apakah telah mempertimbangkan alternatif program yang memberikan hasil yang optimal dengan biaya yang minimal. Akuntabilitas Kebijakan. Akuntabilitas kebijakan terkait dengan petanggungjawaban pembina, pengurus dan pengawas atas kebijakan-kebijakan yang diambil. Dalam sektor publik, dikenal beberapa bentuk dari akuntabilitas, yaitu :

1) Akuntabitas ke atas (upward accountability), menunjukkan adanya kewajiban untuk melaporkan dari pimpinan puncak dalam bagian tertentu kepada pimpinan eksekutif, seperti seorang dirjen kepada menteri.

2) Akuntabilitas keluar (outward accountability), bahwa tugas pimpinan untuk melaporkan, mengkonsultasikan dan menanggapi kelompok-kelompok klien dan stakeholders dalam masyarakat.

3) Akuntabilitas ke bawah (downward accountability), menunjukkan bahwa setiap pimpinan dalam berbagai tingkatan harus selalu mengkomunikasikan dan mensosialisasikan berbagai kebijakan kepada bawahannya karena sebagus apapun suatu kebijakan hanya akan berhasil manakala dipahami dan dilaksanakan oleh seluruh pegawai.

Akuntabilitas publik juga melekat pada fungsi pengendalian dan pengawasan, maka informasi yang disajikan terutama aspek pelaporan keuangan kepada publik harus auditable atau dapat diaudit oleh baik aparat internal dan eksternal pengawasan fungsional Badan Pemeriksan Keuangan (BPK) dan Badan Pengawas Daerah (Bawasda) maupun auditor lainnya yang terkait. Akuntabilitas publik dalam laporan keuangan daerah pengaturannya dalam PSAP Nomor 1 merupakan peranan dan tujuan pelaporan keuangan antara lain : 
a. Untuk menyediakan informasi yang relevan mengenai posisi keuangan dan seluruh transaksi yang dilakukan suatu entitas pemerintah selama satu periode pelaporan

b. Untuk membandingkan realisasi pendapatan dan belanja dengan anggaran yang telah ditetapkan, menilai kondisi keuangan, mengevaluasi aktifitas dan efisiensi suatu entitas, dan membantu menentukan ketaatannya terhadap peraturan perundang-undangan

c. Untuk kepentingan akuntabilitas, manajerial, transparansi, dan keseimbangan antar generasi.

\section{Hubungan Aksesibilitas Laporan Keuangan Terhadap Akuntabilitas Publik}

Teori lain pun muncul untuk menghubungkan akuntabilitas laporan keuangan dan aksesibilitas publik. Seperti yang dikemukakan oleh Mardiasmo (2005 : 23) yaitu:

"Laporan keuangan pemerintah merupakan hak publik yang harus diberikan oleh pemerintah, baik pusat maupun daerah. Hak publik atas informasi keuangan muncul sebagai konsekuensi konsep pertanggungjawaban publik. Pertanggungjawaban publik mensyaratkan organisasi publik untuk memberikan laporan keuangan sebagai bukti pertanggungjawaban dan pengelolaan (accountability dan stewardship)".

Akuntabilitas yang efektif tergantung kepada aksesibilitas publik terhadap laporan pertanggungjawaban maupun laporan temuan yang dapat dibaca dan dipahami. Dalam demokrasi yang terbuka, akses ini diberikan olehmedia, seperti surat kabar, majalah, radio, stasiun televisi, dan website (internet), dan forum yang memberikan perhatian langsung atau peranan yang mendorong akuntabilitas pemerintah terhadap masyarakat.

\section{Kerangka Analisis}

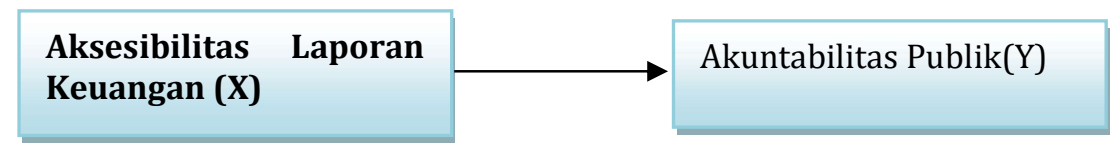

Gambar 1. Kerangka Analisis

\section{HASIL PENELITIAN DAN PEMBAHASAN Karakteristik Responden}

Dalam penelitian ini, yang menjadi responden penelitian sebanyak 20 orang yang terdiri dari 5 orang anggota DPRD, 5 orang pejabat di Bappeda, dan 10 orang mahasiswa. Dimana mahasiswa ini terdiri dari 7 orang mahasiswa S1 murni, 2 orang mahasiswa S1 konfersi, dan 1 orang mahasiswa S2. Responden yang diambil ini merupakan orang-orang yang mengerti, memahami, dan menggunakan hasil laporan keuangan yang akuntabel. Karakteristik responden dirinci berdasarkan kelompok umur, jenis kelamin, dan tingkat pendidikan.

a. Karakteristik Responden Berdasarkan Jenis Kelamin

Karakteristik responden berdasarkan jenis kelamin dapat dilihat pada gambar 2.

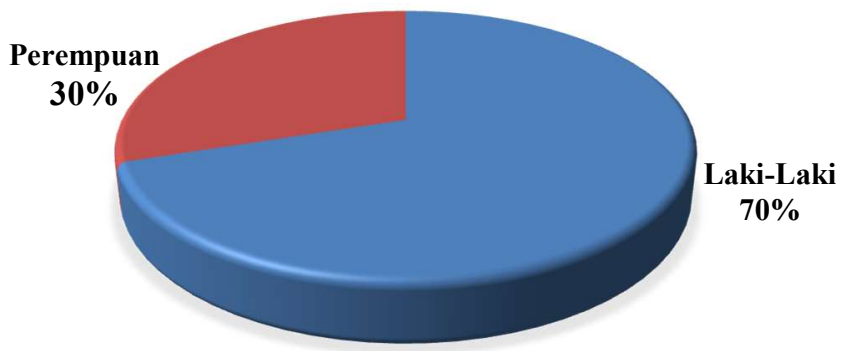

Sumber : Hasil penelitian, data diolah 2016

Gambar 2. Jumlah Responden Berdasarkan Jenis Kelamin

Berdasarkan gambar 2 di atas dapat diketahui bahwa yang menjadi responden adalah laki-laki sebanyak 14 orang dengan persentase $70 \%$, dan responden perempuan sebanyak 6 orang dengan 
persentase 30\%. Hal ini menunjukkan bahwa responden laki-laki lebih banyak menduduki jabatan strategis dalam suatu organisasi

b. Karakteristik Responden Berdasarkan Kelompok Umur

Karakteristik responden berdasarkan kelompok umur dapat dilihat pada gambar 3.

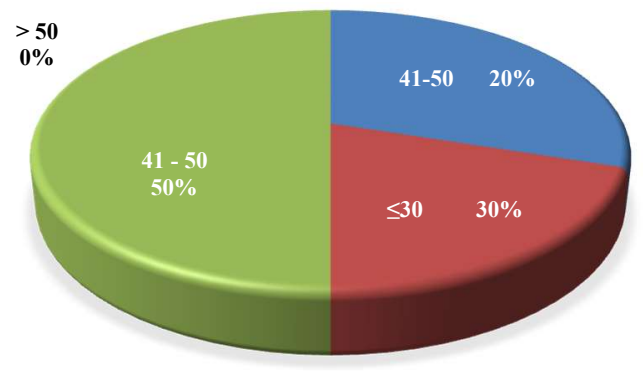

Sumber : Hasil penelitian, data diolah 2016

Gambar 3. Jumlah Responden Berdasarkan Kelompok Umur

Berdasarkan gambar 3 di atas dapat diketahui bahwa jumlah responden berumur $\leq 30$ tahun sebanyak 6 orang dengan persentase 30\%, responden berumur 31-40 tahun sebanyak 4 orang dengan persentase 20\%, responden berumur 41-50 tahun yaitu sebanyak 10 orang dengan persentase 50\%, dan berumur diatas 50 tahun sebanyak 0 orang atau $0 \%$. Hal ini menunjukkan bahwa responden berada pada umur produktif kerja yaitu 15-64 tahun (Undang-Undang Nomor 13 tahun 2003)

c. Karakteristik Responden Berdasarkan Tingkat pendidikan

Karakteristik responden berdasarkan tingkat pendidikan dapat dilihat pada gambar 4 .

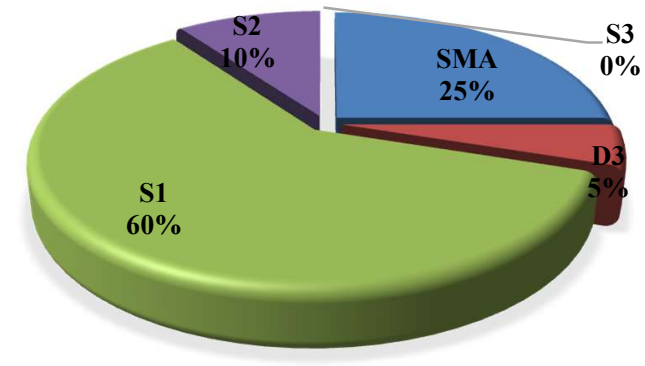

Sumber : Hasil penelitian, data diolah 2016

Gambar 4. Jumlah Responden Berdasarkan Tingkat Pendidikan

Berdasarkan gambar $4 \mathrm{di}$ atas dapat diketahui bahwa responden dengan tingkat pendidikan SMA sebanyak 5 orang dengan persentase 25\%, responden dengan tingkat pendidikan D3 yaitu sebanyak 1 orang, responden dengan tingkat pendidikan S1 yaitu sebanyak 12 orang dengan persentase $60 \%$, dan responden dengan tingkat pendidikan S2 sebanyak 2 orang dengan persentase 10\%. Hal ini menunjukkan bahwa responden memiliki kemampuan untuk mengerti dan memahami mengenai hal yang diteliti.

\section{Jawaban Responden Tentang Variabel Aksesibilitas Laporan Keuangan dan Akuntabilitas Publik}

a. Variabel Aksesibilitas Laporan Keuangan

Adapun jawaban responden terhadap variabel aksesibilitas laporan keuangan dapat di lihat pada tabel 1. 
Tabel 1. Jawaban responden terhadap variabel aksesibilitas laporan keuangan

\begin{tabular}{|c|c|c|c|c|c|c|c|c|c|}
\hline \multirow{2}{*}{ No } & \multirow{2}{*}{ Pernyataan } & \multicolumn{5}{|c|}{ Jawaban } & \multirow{2}{*}{ Jumlah } & \multirow{2}{*}{$\begin{array}{l}\text { Skor } \\
\text { Total }\end{array}$} & \multirow{2}{*}{$\begin{array}{l}\text { Rata- } \\
\text { Rata }\end{array}$} \\
\hline & & SB & B & $\mathrm{CB}$ & TB & STB & & & \\
\hline 1 & $\begin{array}{l}\text { Pemda telah membuat } \\
\text { laporan keuangan }\end{array}$ & 10 & 8 & 2 & 0 & 0 & 20 & 88 & 4,40 \\
\hline 2 & $\begin{array}{l}\text { Pemda telah menyediakan } \\
\text { informasi laporan keuangan } \\
\text { yang dibutuhkan }\end{array}$ & 9 & 8 & 3 & 0 & 0 & 20 & 86 & 4,30 \\
\hline 3 & $\begin{array}{l}\text { Laporan yang dibuat telah } \\
\text { sesuai dengan kebutuhan } \\
\text { pengguna }\end{array}$ & 8 & 9 & 3 & 0 & 0 & 20 & 85 & 4,25 \\
\hline 4 & $\begin{array}{l}\text { Laporan yang dibuat telah } \\
\text { dapat membantu pengguna } \\
\text { dalam mengambil } \\
\text { keputusan ekonomi yang } \\
\text { bersifat finansial }\end{array}$ & 7 & 7 & 6 & 0 & 0 & 20 & 81 & 4,05 \\
\hline 5 & $\begin{array}{l}\text { Laporan keuangan yang } \\
\text { dibuat oleh Pemda relevan } \\
\text { (tepat waktu dan lengkap) }\end{array}$ & 6 & 11 & 3 & 0 & 0 & 20 & 83 & 4,15 \\
\hline 6 & $\begin{array}{l}\text { Laporan keuangan yang } \\
\text { dibuat andal yaitu berisi } \\
\text { informasi yang memiliki } \\
\text { karakteristik penyajian } \\
\text { jujur, veriability, dan netral. }\end{array}$ & 6 & 13 & 1 & 0 & 0 & 20 & 85 & 4,25 \\
\hline 7 & $\begin{array}{l}\text { Laporan keuangan yang } \\
\text { dibuat oleh Pemdadapat } \\
\text { dipahami oleh pengguna }\end{array}$ & 5 & 13 & 2 & 0 & 0 & 20 & 83 & 4,15 \\
\hline 8 & $\begin{array}{llr}\text { Laporan keuangan yang } \\
\text { dibuat Pemda dapat } \\
\text { dibandingkan dengan priode } \\
\text { sebelumnya (masa lalu) }\end{array}$ & 7 & 10 & 3 & 0 & 0 & 20 & 84 & 4,20 \\
\hline 9 & $\begin{array}{lrr}\text { Laporan } & \text { keuangan yang } \\
\text { dibuat oleh } & \text { Pemdadapat } \\
\text { dilihat } & \text { di } & \text { papan } \\
\text { pengumuman Pemda } & \\
\end{array}$ & 9 & 6 & 5 & 0 & 0 & 20 & 84 & 4,20 \\
\hline 10 & $\begin{array}{l}\text { Laporan keuangan yang } \\
\text { dibuat oleh Pemdadapat } \\
\text { dilihat di surat kabar }\end{array}$ & 9 & 7 & 4 & 0 & 0 & 20 & 85 & 4,25 \\
\hline 11 & $\begin{array}{l}\text { Laporan keuangan dapat } \\
\text { dilihat di kantor Pemda }\end{array}$ & 11 & 6 & 3 & 0 & 0 & 20 & 88 & 4,40 \\
\hline 12 & $\begin{array}{l}\text { Laporan keuangan selalu di } \\
\text { publikasikan di surat kabar } \\
\text { setiap tahunnya }\end{array}$ & 11 & 5 & 4 & 0 & 0 & 20 & 87 & 4,35 \\
\hline & Rata-Rata & & & & & & & & 4,25 \\
\hline
\end{tabular}

Sumber : Hasil Analisis Kuisioner, 2016

Keterangan :
$1,00-1,80$
= Sangat Tidak Baik
$1,81-2,60$
$=$ Tidak Baik
$3,41-4,20$
$=$ Baik
$2,61-3,40$
= Cukup Baik
$4,21-5,00$
= Sangat Baik

Dari tabel $1 \mathrm{di}$ atas terlihat rata-rata persepsi responden terhadap variabel aksesibilitas laporan keuangan sebesar 4,25. Nilai tersebut menunjukkan bahwa persepsi responden berada di antara 4,21 - 5,00, sehingga dapat dikatakan bahwa aksesibilitas laporan keuangan pada Pemerintah Daerah Kabupaten Bengkulu Utara berada pada kondisi sangat baik.

b. Variabel Akuntabilitas Publik

Hasil kuesioner mengenai variabel akuntabilitas pubik dapat di lihat pada tabel 2. 
Tabel 2. Jawaban responden terhadap variabel akuntabilitas publik

\begin{tabular}{|c|c|c|c|c|c|c|c|c|c|}
\hline \multirow{2}{*}{ No } & \multirow{2}{*}{ Pernyataan } & \multicolumn{5}{|c|}{ Jawaban } & \multirow{2}{*}{ Jumlah } & \multirow{2}{*}{$\begin{array}{l}\text { Skor } \\
\text { Total }\end{array}$} & \multirow{2}{*}{$\begin{array}{l}\text { Rata- } \\
\text { Rata }\end{array}$} \\
\hline & & SB & B & $\overline{\mathrm{CB}}$ & TB & STB & & & \\
\hline 1 & $\begin{array}{l}\text { Laporan pertanggungjawaban } \\
\text { yang dibuat sesuai dengan } \\
\text { peraturan perundang- } \\
\text { undangan yang berlaku }\end{array}$ & 14 & 5 & 1 & 0 & 0 & 20 & 93 & 4,65 \\
\hline 2 & $\begin{array}{l}\text { Laporan pertanggungjawaban } \\
\text { yang dibuat tidak memiliki } \\
\text { cacat hukum }\end{array}$ & 14 & 6 & 0 & 0 & 0 & 20 & 94 & 4,70 \\
\hline 3 & $\begin{array}{l}\text { Laporan pertanggungjawaban } \\
\text { yang disampaikan memiliki } \\
\text { unsur kejujuran yang tinggi }\end{array}$ & 15 & 4 & 1 & 0 & 0 & 20 & 94 & 4,70 \\
\hline 4 & $\begin{array}{l}\text { Laporan pertanggungjawaban } \\
\text { yang dibuat dengan tidak } \\
\text { menyalahgunakan jabatan }\end{array}$ & 13 & 5 & 2 & 0 & 0 & 20 & 91 & 4,55 \\
\hline 5 & $\begin{array}{l}\text { Pemda melaksanakan tugas } \\
\text { sudah cukup baik dalam hal } \\
\text { kecukupan sistem informasi } \\
\text { akuntansi }\end{array}$ & 11 & 8 & 1 & 0 & 0 & 20 & 90 & 4,50 \\
\hline 6 & $\begin{array}{l}\text { Pemda } r \text { melaksanakan } \\
\text { akuntabilitas } \quad \text { sesuai dengan } \\
\text { sistem informasi manajemen }\end{array}$ & 13 & 6 & 1 & 0 & 0 & 20 & 92 & 4,60 \\
\hline 7 & 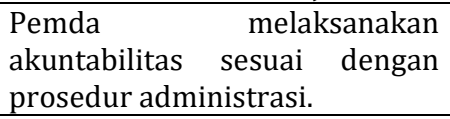 & 13 & 7 & 0 & 0 & 0 & 20 & 93 & 4,65 \\
\hline 8 & $\begin{array}{l}\text { Pemda } \\
\text { akuntabilitas dengan proses } \\
\text { termanifestasikan } \\
\text { pemberian pelayanan publik } \\
\text { yang cepat, responsif, dan } \\
\text { murah biaya }\end{array}$ & 16 & 4 & 0 & 0 & 0 & 20 & 96 & 4,80 \\
\hline 9 & $\begin{array}{l}\text { Akuntabilitas Program telah } \\
\text { mempertimbangkan apakah } \\
\text { tujuan yang ditetapkan telah } \\
\text { tercapai }\end{array}$ & 15 & 5 & 0 & 0 & 0 & 20 & 95 & 4,75 \\
\hline 10 & $\begin{array}{l}\text { Akuntabilitas Program telah } \\
\text { mempertimbangkan alternatif } \\
\text { program yang memberikan } \\
\text { hasil yang optimal dengan biaya } \\
\text { yang minimal }\end{array}$ & 12 & 8 & 0 & 0 & 0 & 20 & 92 & 4,60 \\
\hline 11 & $\begin{array}{l}\text { Pemda telah mengurus dan } \\
\text { membina atas kebijakan yang } \\
\text { dibuat dengan } \\
\text { mempertimbangkan yang } \\
\text { memberikan hasil yang optimal } \\
\text { dengan biaya yang minimal }\end{array}$ & 13 & 6 & 1 & 0 & 0 & 20 & 92 & 4,60 \\
\hline 12 & $\begin{array}{l}\text { Pemda telah mengawasi atas } \\
\text { kebijakan-kebijakan } \\
\text { diambil }\end{array}$ & 17 & 2 & 1 & 0 & 0 & 20 & 96 & 4,80 \\
\hline & Rata-rata & & & & & & & & 4,66 \\
\hline
\end{tabular}

Sumber : Hasil Analisis Kuisioner, September 2014

Keterangan :

$$
\begin{array}{ll}
1,00-1,80 & =\text { Sangat Tidak Baik } \\
1,81-2,60 & =\text { Tidak Baik } \\
3,41-4,20 & =\text { Baik } \\
2,61-3,40 & =\text { Cukup Baik } \\
4,21-5,00 & =\text { Sangat Baik }
\end{array}
$$

Dari tabel 2 di atas terlihat rata-rata persepsi responden terhadap variabel akuntabilitas publik sebesar 4,66. Nilai tersebut menunjukkan bahwa persepsi responden berada di antara 4,21 - 5,00, 
sehingga dapat dikatakan bahwa akuntabilitas publik pada Pemerintah daerah Kabupaten Bengkulu Utara berada pada kondisi sangat baik.

\section{Korelasi Rank Spearman antara Aksesibilitas Laporan Keuangan Terhadap Akuntabilitas Publik}

Berdasarkan perhitungan koefisien korelasi Rank Spearman antara aksesibilitas laporan keuangan dengan akuntabilitas publik, dimana :

$$
\begin{aligned}
& \text { Nilai } \sum \mathrm{d}^{2}=496 \\
& \mathrm{n} \quad=20 \\
& r s=1-\frac{6 \sum \mathrm{d}^{2}}{n\left(n^{2}-1\right)} \\
& r s=1-\frac{6 \times 496}{20\left(20^{2}-1\right)} \\
& r s=1-\frac{6 \times 496}{20(399)} \\
& r s=1-\frac{2976}{7980} \\
& r s=1-0,37 \\
& r s=0,63
\end{aligned}
$$

Hal ini dapat diberi arti dengan nilai interpestasi koefisien korelasi menurut tabel berikut ini:

Tabel 3. Interpretasi koefisien korelasi

\begin{tabular}{|c|c|}
\hline Interval nilai r & Interpretasi \\
\hline $0,0-0,199$ & sangat lemah \\
\hline $0,20-0,399$ & lemah \\
\hline $0,40-0,599$ & cukup kuat \\
\hline $0,60-0,799$ & kuat \\
\hline $0,80-1,000$ & sangat kuat \\
\hline
\end{tabular}

Sumber: (Sugiono, 2010: 144)

Dari hasil perhitungan maka diperoleh nilai korelasinya sebesar0,63. Hal ini menunjukkan bahwa antara variabel aksesibilitas laporan keuangan (x) dan akuntabilitas publik (y) memiliki hubungan yang kuat, dimana artinya bahwa jika variabel x naik maka variabel y juga akan naik.

\section{Uji Hipotesis}

Untuk mendapatkan hasil hipotesis maka perlu dibandingkan antara $r s$ hitung dangan $r s$ tabel. Pada penelitian ini penulis menggunakan taraf signifikan sebesar $5 \%$ dengan $\mathrm{n}=20$. Dimana nilai $r$ s tabel $=0,450$ dan $r$ s hitung $=0,63$. Hal ini berarti nilai $r s$ hitung $>r s$ tabel $(0,63>0,450)$, maka menunjukkan bahwa terdapat hubungan yang signifikan antara aksesibilitas laporan keuangan dengan akuntablitias publik pada Pemerintah Daerah Kabupaten Bengkulu Utara.

\section{Pembahasan}

Dari hasil penelitian menunjukan bahwa aksesibilitas laporan keuangan pada Pemerintah Kabupaten Bengkulu Utara sangat baik, mulai dari ketersediaan informasi laporan keuangan yang dibutuhkan pengguna dengan sangat baik, kualitas informasi laporan yang sangat baiksesuai dengan amanat Peraturan Pemerintah No. 71 Tahun 2010, serta media publikasi juga sangat baik.

Laporan keuangan yang dibuat oleh Pemerintah Daerah adalah laporan akhir tahun yang berisi Laporan Realisasi Anggaran (LRA) yaitu laporan yang menyediakan informasi mengenai realiasi pendapatan, belanja, transfer, surplus/defisit dan pembiayaan dari suatu entitas pelaporan (SKPD) yang masing-masing dibandingkan dengan anggarannya dan menyediakan informasi yang berguna dalam memprediksi sumber daya ekonomi yang akan diterima untuk mendanai kegiatan pemerintah pusat dan daerah dalam periode mendatang dengan cara menyajikan laporan secara komparatif, laporan Neraca (balance sheet) Daerah yang menunjukan laporan tentang harta atau kekayaan daerah, atau keadaan 
posisi keuangan pada saat tertentu, serta aktiva dan nilai kekayaan daerah selama periode rencana strategi (renstra), serta Catatan atas Laporan Keuangan (CALK) yang merupakan catatan tambahan dan informasi yang ditambahkan ke akhir laporan keuangan untuk memberikan tambahan informasi kepada pembaca dengan informasi lebih lanjut. Catatan atas Laporan Keuangan dapat mencakup informasi tentang hutang, kelangsungan usaha, piutang, kewajiban kontinjensi, atau informasi kontekstual untuk menjelaskan angka-angka keuangan.

Dalam mempublikasikan laporan keuangan Daerah Kabupaten Bengkulu Utara, Pemerintah Daerah telah mempublikasikan laporan keuangan tersebut melalui surat kabar setiap tahunnya sebagai pertanggungjawaban keuangan yang telah dipergunakan setiap tahunnya. Selain itu laporan keuangan ini juga dapat dilihat di website Pemerintah Daerah Kabupaten Bengkulu Utara. Untuk laporan keuangan setiap bulannya, laporan keuangan hanya bisa diakses langsung ke Dinas Pengelolaan Keuangan dan Aset Daerah Kabupaten Bengkulu Utara. Namun untuk dapat memperoleh data yang dibutuhkan tersebut diperlukan surat pengantar yang dapat dipertanggungjawabkan agar tidak ada penyalahgunaan data/informasi.

Pemerintah Daerah memiliki akuntabilitas publik mengenai laporan keuangan yang sangat baik, mulai dari akuntabilitas hukum, akuntabilitas proses, sampai dengan akuntabilitas program dan kebijakan.Laporan pertanggungjawaban yang dibuat oleh Pemerintah Daerah sesuai dengan peraturan perundang-undangan yang berlaku, tidak memiliki cacat hukum, dengan tingkat kejujuran yang tinggi tanpa menyalahgunakan jabatan untuk memperoleh keuntungan pribadi atau golongan tertentu. Laporan pertanggungjawaban ini telah sesuai dengan proses pertanggungjawaban mulai dari penyusunan APBD sampai dengan pertanggungjawaban laporan keuangan sesuai dengan aturan yang berlaku dan sesuai prosedur administrasi ataupun manajemen.

Selain itu, program atau kebijakan yang ada dalam Anggaran Pendapatan dan Belanja Daerah telah mempertimbangkan output yang optimal dengan biaya yang minimal. Serta kebijakan yang diambil selalu diawasi dan dibina agar tidak terjadi pemborosan anggaran untuk programkegiatan yang belum dibutuhkan.

Laporan pertanggungjawaban pemerintah daerah ini disampaikan kepada Badan Pemerikasa Keuangan paling lambat 3 bulan setelah berakhirnya pelaksanaan anggaran tahun sebelumnya, dan Pemerintah Daerah Kabupaten Bengkulu Utara pernah 2 tahun berturut-turut memperoleh penghargaan mengenai laporan pertanggungjawaban keuangan daerah dengan Wajar Tanpa Pengecualian (WTP) yang diberikan oleh Menteri Keuangan Negara. Pada tanggal 21 September 2014 yang lalu, Pemerintah Daerah Kabupaten Bengkulu Utara untuk yang ke 2 kalinya memperoleh penghargaan WTP. Akan tetapi mengalami kemunduran ditahun 2015 dan 2016, dimana Pemerintah Kabupaten Bengkulu Utara tidak dapat meraih hasil audit WTP.

Dari hasil penelitian juga menunjukkan bahwa terdapat hubungan yang signifikan kuat antara aksesibilitas laporan keuangan dan akuntabilitas publik pada Pemerintah Daerah Kabupaten Bengkulu Utarayang terlihat dari nilai $r s$ hitung $>r s$ tabel $(0,63>0,450)$. Artinya bahwa dengan adanya laporan keuangan baru dapat melaksanakan akuntabilitas publik. Laporan keuangan merupakan kunci utama dalam pelaksanaan akuntabilitas publik, karena laporan inilah yang akan dipublikasikan dan dipertanggungjawabkan kepada seluruh masyarakat di Kabupaten Bengkulu Utara. Apakah pemerintah telah melaksanakan tugas dengan baik atau tidak.

\section{KESIMPULAN}

Dari hasil penelitian dapat diambil kesimpulan bahwa terdapat hubungan yang signifikan antara aksesibilitas laporan keuangan dan akuntabilitas publik pada Pemerintah Kabupaten Bengkulu Utara yang terlihat dari nilai $r s$ hitung $>r s$ tabel $(0,63>0,450)$. Sedangkan kekuatan hubungan antara aksesibilitas laporan keuangan dengan akuntabilitas publik adalah kuat yang terlihat dari nilai korelasi 0,63 berada pada interval $0,60-0,799$ dengan interprestasi kuat.

\section{SARAN}

Dari kesimpulan diatas, adapun saran dari penulis dalam penelitian ini adalah mengingat hasil penelitian menunjukkan hubungan yang kuat antara aksesibilitas laporan keuangan dengan akuntabilitas publik maka aksesibilitas laporan keuangan dan akuntabilitas publik pada Pemerintah Daerah Kabupaten Bengkulu Utara lebih ditingkatkan lagi sehingga memperoleh penghargaan terbaik se Indonesia.

\section{DAFTAR PUSTAKA}

Arens. 2003. Auditing and Assurance Service, An Integrated Approach. Englewood Cliffs : New Jaersey Badudu, Yus. 2007. Kamus Kata-Kata Serapan Asing Dalam Bahasa Indonesia.Jakarta : PT. Gramedia. 
Fahmi, Irham. 2012. Analisis Kinerja Keuangan. Bandung : Alfabeta.

Halim, Abdul. 2002. Akuntansi Sektor Publik akuntansi Keuangan Daerah.Jakarta : Salemba Empat.

Jumung,Martin. 2005.Politik Lokal dan Pemerintah Daerah dalam Perspektif Otonomi Daerah. Jakarta :Pustaka Nusantara.

Kusuma, Riyani. 2014. Laporan Keuangan. Jakarta.

(http://riyanikusuma.wordpress.com/2014/04/30/laporan-keuangan-transparan-melindungiinvestor-dan-meningkatkan-kualitas-pasar/)

Mahsun. 2012. Pengukuran Kinerja Sektor Publik. Yogyakarta : BPFEUGM Yogyakarta.

Mardiasmo. 2005. Akuntansi Sektor Publik. Yogyakarta : Andi.

Mirawan. 2009. Evaluasi Kinerja Sumber Daya Manusia. Jakarta : Salemba Empat.

Mulyadi. 2008. Manajemen Kinerja Sektor Publik. Yogyakarta : YKPN.

Rai, I Gusti Agung. 2008. Audit Kinerja Pada Sektor Publik. Jakarta : Salemba.

Riduwan. 2009. Pengantar Statistika. Bandung : Alfabeta.

Sugiyono. 2010. Metode Penelitian Pendidikan. Bandung : Alfabeta.

Triton. 2005. SPSS 13.0 Terapan Riset Statistik Parametrik. Yogyakarta : Andi

-2004.Undang-Undang Nomor 33 tahun 2004 tentang Perimbangan Keuangan antara Pemerintah Pusat dan Pemerintah Daerah.

-2010. Peraturan Pemerintah No. 71 Tahun 2010 Tentang Standar Akuntansi Pemerintah.

2010. Pelatihan Dasar Dasar Akuntansi - Sistem Akuntansi Daerah - Badan Pengawasan Keuangan dan Pembangunan.Deputi Pengawasan Bidang Penyelenggaraan Keuangan Daerah.

2012. Peraturan Daerah Nomor 2 Tahun 2012 tentang Perubahan atas Peraturan Daerah Nomor 1 Tahun 2008 tentang Susunan Organisasi dan Tata Kerja Perangkat daerah Kabupaten Bengkulu Utara

2013. Laporan keuangan Pemerintah Daerah Kabupaten Bengkulu Utara Tahun Anggaran 2013. 